\title{
PERAN KEPUASAAN DALAM MEMEDIASI PENGALAMAN BERBELANJA TERHADAP MINAT BELI KEMBALI
}

\author{
Nyoman Ayu Nidya Larasati Dewi ${ }^{1}$ \\ A.A.Gede Agung Artha Kusuma ${ }^{2}$ \\ ${ }^{1,2}$ Fakultas Ekonomi Dan Bisnis Universitas Udayana (Unud), Bali, Indonesia \\ email: nidyalarasati@yahoo.com
}

\begin{abstract}
ABSTRAK
Tujuan dari penelitian ini adalah untuk mengetahui pengaruh pengalaman berbelanja terhadap minat beli kembali, serta mengetahui peran kepuasan dalam memediasi pengaruh pengalaman berbelanja dan terhadap minat beli kembali. Penelitian dilakukan di Zara Beachwalk dengan sampel sebanyak 95 orang yang merupakan konsumen produk fashion Zara. Teknik sampling yang digunakan adalah non probability sampling dengan metode purposive sampling. Pengumpulan data dilakukan dengan penyebaran kuesioner kepada para konsumen produk fashion Zara di Beachwalk. Berdasarkan hasil analisis, ditemukan bahwa variabel pengalaman berbelanja dan kepuasan berpengaruh positif dan signifikan terhadap minat beli kembali. Hasil penelitian ini juga menunjukkan bahwa variabel kepuasan memediasi pengaruh pengalaman berbelanja terhadap minat beli kembali secara parsial. Saran yang dapat diberikan kepada manajemen produk fashion Zara di Beachwalk adalah manajemen harus mampu menciptakan pengalaman berbelanja yang baik bagi konsumen sehingga kepuasan yang dirasakan ketika berbelanja akan meningkat dan minat beli kembali konsumen akan menjadi tinggi.
\end{abstract}

Kata kunci: minat beli kembali, kepuasan, pengalaman berbelanja

\begin{abstract}
The purpose of this study was to determine the effect of shopping experience on buying interest, and to know the role of satisfaction in mediating the effect of shopping experience and on the interest in buying back. The study was conducted at Zara Beachwalk with a sample of 95 people who are consumers of Zara's fashion products. The sampling technique used is non probability sampling with a purposive sampling method. Data collection is done by distributing questionnaires to consumers of Zara fashion products at Beachwalk. Based on the results of the analysis, it was found that shopping experience and satisfaction variables had a positive and significant effect on interest in repurchasing. The results of this study also indicate that the satisfaction variable mediates the influence of shopping experience on partial repurchase interests. The advice that can be given to the management of Zara's fashion products at Beachwalk is that management must be able to create a good shopping experience for consumers so that the satisfaction felt when shopping will increase and consumer buying interest will be high.

Keywords: repurchase intention, satisfaction, shopping experience
\end{abstract}




\section{PENDAHULUAN}

Dewasa ini fashion memiliki pengaruh besar terhadap masyarakat di Indonesia khususnya di Bali. Perkembangan fashion di Bali cukup pesat, dapat dilihat dari banyaknya mall atau outlet yang menjual berbagai macam gaya fashion yang bervariasi. Fashion selalu mengalami perubahan dan perkembangan di setiap tahunnya yang menjadi daya tarik masyarakat untuk mengikutinya. Di era modern ini fashion bukan hanya kebutuhan dasar saja namun juga menjadi pemenuhan gaya hidup atau lifestyle.

Bali merupakan kawasan pariwisata yang jumlah penduduk setiap tahunnya semakin meningkat, banyaknya wisatawan yang datang dan membawa gaya berpakaian mereka ke bali yang membawa pengaruh bagi fashion yang ada di bali. Sehingga membuat masyarakat bali semakin konsumtif, hal ini dapat dilihat dari kenaikan data Indeks Tendensi Konsumen (ITK). ITK merupakan indeks yang menggambarkan kondisi ekonomi konsumen pada triwulan berjalan dan perkiraan triwulan mendatang. ITK disusun berdasarkan beberapa komponen yang terkait dengan ekonomi rumah tangga seperti penghasilan, pengaruh inflansi / kenaikan harga terhadap kemampuan konsumsi tingkat konsumsi barang dan jasa pada triwulan bersangkutan (BPS,2016). Kondisi ekonomi konsumen mengalami peningkatan di triwulan II-2018, dilihat dari angka ITK di triwulan ini yang mencapai 124,89 secara umum posisi ini lebih nyaman dibandingkan dengan triwulan sebelumnya dengan peningkatan sebesar 18,59 poin dari triwulan sebelumnnya yang tercatat sebesar 106,30.

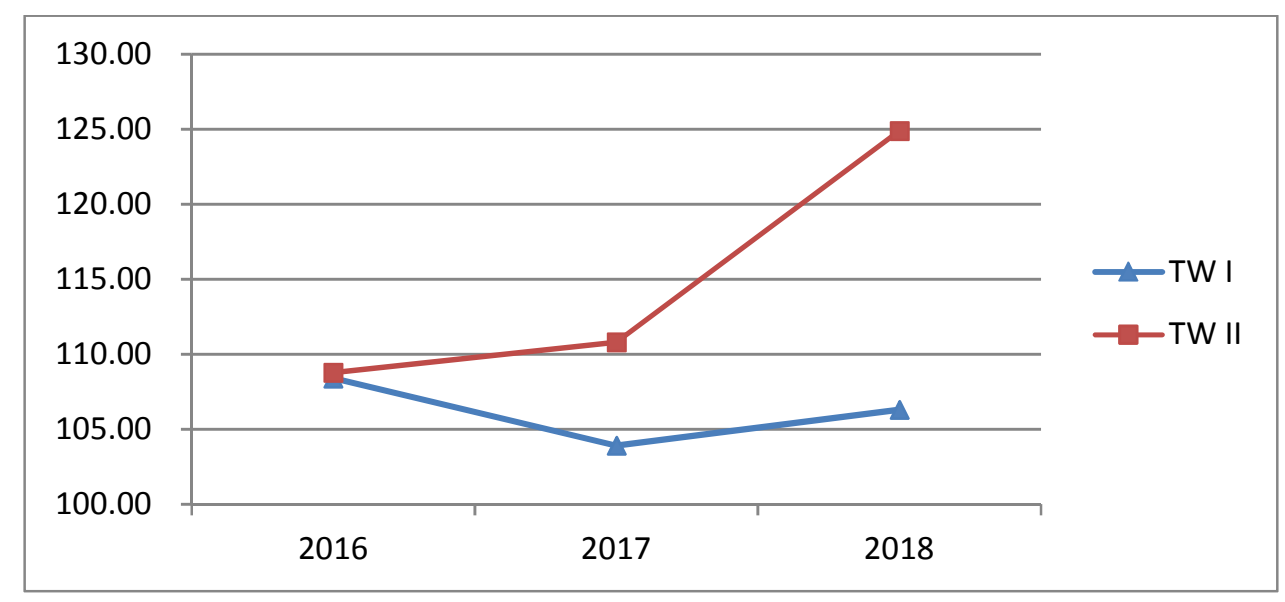

Gambar 1. Indeks Tedensi Konsumen Bali

Sumber: Berita Resmi Statistik Provinsi Bali, 2018

Meningkatnya ITK di Bali setiap tahunnya merupakan peluang bagi perusahaan untuk memperluas pangsa pasarnya sehingga dapat meningkatkan keuntungan perusahaan. Di era globalisasi, perkembangan teknologi dan informasi yang sangat cepat menyebabkan semakin mudahnya informasi yang di dapatkan oleh konsumen termasuk informasi mengenai trend fashion terbaru. Mudahnya informasi yang di dapat menyebabkan masyarakat menjadi tertarik untuk membeli produk fashion sesuai dengan trend yang ada. Fashion merupakan 
cermin dari karakter seseorang, selain itu karena trend fashion terus berkembang seiring perkembangan jaman, banyaknya perusahaan fashion global yang membuka outlet fashionnya di bali meningkatkan keanekaragaman model fashion sehingga membuat masyarakat bali semakin konsumtif dalam membeli produk fashion.

Banyaknya perusahaan fashion di Indonesia yang saling bersaing membuat peluang untuk memenangkan pangsa pasar semakin kecil. Perusahaan dituntut untuk memenuhi keinginan dan kebutuhan konsumen untuk memperoleh keunggulan yang kompetitif, dalam menarik minat beli konsumen baru maupun lama perusahaan tidak hanya memperhatikan produk yang ditawarkan namun juga memperhatikan kenyamanan konsumen dalam proses pembelian.

Minat beli ulang terjadi apabila perusahaan mampu membuat para pelanggan puas dengan produk dan layanan yang diberikan. Niat membeli dan sikap loyal dari konsumen adalah hal terpenting bagi sebuah perusahaan untuk mempertahankan eksistensinya dan agar dapat bertahan dalam persaingan dengan menjaga konsumen yang ada dan menarik perhatian konsumen baru.Seorang konsumen yang memperoleh respon positif atas tindakan masa lalu akan terjadi penguatan dengan dimilikinya pemikiran positif atas tindakan yang di terimanya memungkinkan individu untuk melakukan pembelian secara berulang Pujiati et al. (2016). Minat beli ulang yang tinggi mencerminkan tingkat kepuasan yang tinggi dari konsumen ketika memutuskan untuk membeli suatu produk Faradisa et al. (2016) Menurut Fornell dalam Hendarsono dan Sugiharto (2013) mengatakan bahwa konsumen yang merasa puas akan melakukan kunjungan ulang di masa mendatang dan juga memberitahukan kepada orang lain atas produk atau jasa yang dirasakan.

Kepuasan pelanggan merupakan kunci yang penting untuk dapat mempertahankan pelanggan, Kepuasan pelanggan tidak hanya sekedar akan kembali membeli ulang produk atau jasa akan tetapi juga akan merekomendasikan ke orang lain mengenai pengalaman konsumen tersebut selama menggunakan produk tersebut, sehingga usaha tersebut lebih terkenal dan mendapatkan banyak konsumen. Kepuasan konsumen dapat ditingkatkan dengan cara meningkatkan kualitas produk dan pelayanan, untuk memberikan pelayanan yang berkualitas perusahaan harus memahami apa yang di harapkan konsumen dari produk dan jasa yang diberikan Artiningtyas et al. (2015).

Ketatnya persaingan pada bisnis di bidang fashion membuat perusahaan harus memiliki strategi untuk mempertahankan posisinya.Kepuasan merupakan salah satu faktor yang dapat mempengaruhi niat beli ulang, perilaku konsumen pada masa mendatang dipengaruhi oleh kepuasan dan ketidakpuasaan konsumen (Yolandari,2018) Penelitian sebelumnya menemukan bahwa kepuasan pelanggan berpengaruh positif dan signifikan terhadap niat membeli kembali Lin et al. (2014). Saat perusahaan mampu memberikan kepuasaan pada konsumen maka konsumen akan melakukan pembelian kembali pada perusahaan tersebut akan semakin besar. Kepuasaan konsumen dapat dibentuk melalui pengalaman berbelanja.

Pengalaman memberikan memori atau kenangan tersendiri bagi konsumen. Kenangan yang positif akan memberikan keuntungan bagi perusahaan, selain itu 
konsumen akan menceritakan pengalaman tersebut kepada orang lain sehingga menarik untuk ikut mengkonsumsi produk atau jasa tersebut. Pengalaman berbelanja terjadi tidak hanya melalui produk yang ditawarkan tetapi bisa melalui kenyamanan yang dirasakan konsumen pada saat menjelajah toko. Marques et al. (2013) juga menekankan pentingnya tata letak dan design dalam menciptakan peluang bagi pelanggan untuk menjelajah lebih jauh, sementara itu juga memiliki hubungan dengan kepuasan.

Pengalaman positif dapat memberikan kepuasaan bagi pelanggannya dan dapat menciptakan niat beli ulang. Seperti penelitian sebelummnya yang mengatakan bahwa lingkungan dalam toko mempengaruhi keadaan emosional dan tingkat kepuasan pelanggan Lichtle and Plichon (2014). Jika pengalaman yang diterima konsumen ternyata memberikan rasa kepuasan, maka akan meningkatkan minat belinya dan akan membuat konsumen melakukannya lagi di masa depan. Namun, jika pengalaman negatif yang diterima maka pelanggan akan enggan untuk melakukannya lagi di masa depan Alwafi, Fachrizi et al. (2016). maka dalam penelitian ini akan membahas tentang peran kepuasan dalam memediasi pengalaman berbelanja terhadap niat beli kembali.

Pengalaman (Experience) adalah peristiwa pribadi yang terjadi sebagai jawaban atas beberapa rangsangan. Pengalaman atau experience melibatkan seluruh peristiwa dalam setiap kehidupan. Dengan kata lain, sebagai perusahaan harus menata lingkungan yang benar untuk pelanggan dan mengetahui apa yang sebenarnya diinginkan pelanggan. Pengalaman atau experience pada umumnya bukan dihasilkan atas diri sendiri tapi bersifat membujuk atau secara psikologi, pengalaman adalah sesuatu hal yang terjadi tanpa unsur kesengajaan Agus Rahayu et al. (2013). Pengalaman konsumen ketika berbelanja dapat menjadi suatu motivasi konsumen untuk melakukan pembelian. Suasana toko yang nyaman adalah atribut yang paling sering diperhatikan oleh konsumen ketika berbelanja dan dihubungkan dalam kepuasan berbelanja. Selain itu pengalaman berbelanja yang menyenangkan menjadi hubungan yang kuat terhadap kepuasan konsumen secara keseluruhan (Tambunan, Samuel dan Wiwik Handayani,2017). Pengalaman berbelanja dapat dirasakan langsung saat konsumen melakukan proses pembelian. Disaat proses pembelian tersebut perusahaan diharapkan mampu untuk memberikan kenyaman kepada konsumen.

Gilboa dan Vinai Yavetz (2013) mengidentifikasi tiga pengalaman belanja yaitu: Gairah atau godaan yang meluap, membeli dan mendapatkan sesuatu yang menyenangkan, Pengalaman interaktif, merasakan pengalaman dan mendapatkan pelajar yang berharga dari membeli suatu barang.Belanja sebagai sarana sosial, mendapatkan interaksi dengan teman dan keluarga maupun orang lain.

Setiap organisasi jasa yang berorientasi pada pelanggan wajib memberikan kesempatan seluas-luasnya bagi para pelanggannya untuk menyampaikan saran, kritik, pendapat, dan keluhan mereka. Media yang digunakan bisa berupa kontak saran yang diletakkan di tempat-tempat startegis (yang mudah diakses atau sering dilalui pelanggan), saluran telepon khusus bebas pulsa, sehingga memungkinkannya untuk bereaksi dengan tanggap dan cepat mengatasi masalahmasalah yang timbul. 
Salah satu metode untuk memperoleh gambaran mengenai kepuasan pelanggan adalah dengan memeperkerjakan orang untuk berperan sebagai pelanggan potensial jasa perusahaan dan pesaing.

Perusahaan segyogyanya menghubungi para pelanggan yang telah berhenti membeli atau yang telah beralih pemasok agar dapat memahami mengapa hal itu terjadi dan supaya dapat mengambil kebijakan perbaikan atau penyempurnaan selanjutnya.

Umumnya sebagiaan besar penelitian mengenai kepuasan pelanggan menggunakan metode survei, baik via pos, telepon, e-mail, maupun wawancara langsung. Melalui survei perusahaan akan memperoleh tanggapan dan umpan balik langsung dari pelanggan danjuga memberikan sinyal positif bahwa perusahaan menaruh perhatian terhadap mereka.

Niat membeli dan sikap loyal dari konsumen adalah hal terpenting bagi sebuah perusahaan untuk mempertahankan eksistensinya dan agar dapat bertahan dalam persaingan dengan menjaga konsumen yang ada dan menarik perhatian konsumen baru. Perusahaan harus memberikan tingkat pelayanan yang baik dan tenaga kerja yang berkualitas supaya memberi kesan pengalaman positif kepada konsumen dan pada akhirnya dapat tercipta rasa kepuasan dan percaya (trust) dari konsumen terhadap perusahaan. Selanjutnya diharapkan dapat tercipta niat untuk membeli produk tersebut. (Adji,2014) Minat beli ulang merupakan minat pembelian yang didasarkan atas pengalaman pembelian yang telah dilakukan di masa lalu. Dalam hal ini dapat dikatakan bahwa hasil dari pengalaman membeli sebelumnya sangat berpengaruh dengan pembelian selanjutnya. Jika pada pembelian pertama mendapatkan hasil yang memuaskan, konsumen akan mengalami minat pembelian ulang atau selanjutnya. Jika pembelian pertama memiliki hasil yang buruk, maka tidak aka nada pembelian selanjutnya atau pembelian ulang. Minat beli ulang yang tinggi mencerminkan tingkat kepuasan yang tinggi dari konsumen ketika memutuskan untuk membeli suatu produk (Faradisa dkk., 2016)

Berdasarkan pengertian diatas dapat disimpulkan bahwa niat beli merupakan perasaan dalam diri seseorang yang mendorong terjadinya pembelian suatu produk atau jasa yang timbul karena mendapatkan informasi mengenai produk atau jasa tertentu.

Niat dianggap sebagai penangkap atau perantara faktor - faktor motivasional yang mempunyai dampak pada suatu perilaku. Niat menunjukkan seberapa kuat seseorang berani mencoba. Niat juga menunjukkan seberapa banyak upaya yang direncanakan seseorang untuk dilakukan.Niat adalah paling dekat berhubungan dengan perilaku selanjutnya Pelanggan yang berkomitmen memiliki keterikatan emosional terhadap merek atau perusahaan yang ditujunya.

Menurut Ferdinand dalam Soleha dkk. (2017) Indikator yang digunakan untuk variabel minat pembelian ulang adalah kecendrungan seseorang untuk selalu membeli ulang produk yang telah digunakan. Kecendrungan seseorang untuk mereferensikan produk yang sudah dibelinya, agar juga dibeli oleh orang lain dengan referensi pengalaman penggunanya. Minat yang menggambarkan perilaku seseorang yang selalu memiliki preferensi utama pada produk yang telah digunakan. Minat yang menggambarkan perilaku seseorang yang selalu mencari 
informasi mengenai produk yang dminatinya dan mencari informasi untuk mendukung sifat-sifat positif dari produk tersebut Menurut Corin et al. di kutip dalam Hendarsono \& Sugiharto (2013) pengertian minat beli ulang adalah perilaku pelanggan dimana pelanggan merespon positif terhadap apa yang telah diberikan oleh suatu perusahaan dan berminat untuk melakukan kunjungan kembali atau mengkomsusi kembali produk perusahaan tersebut. Menurut Fornell dalam Hendarsono dan Sugiharto (2013) mengatakan bahwa konsumen yang merasa puas akan melakukan kunjungan ulang di masa mendatang dan juga memberitahukan kepada orang lain atas produk atau jsa yang dirasakan.

Mempertahankan pelanggan berarti mengharapkan pelanggan melakukan pembelian ulang atas produk maupun jasa pada saat kebutuhan yang sama muncul sewaktu-waktu. Menurut Kotler, di kutip dalam Sembiring dkk. (2014) Kepuasan pelanggan adalah perasaan senang atau kecewa seseorang yang muncul setelah membandingkan antara harapan terhadap kenyataan yang diperoleh. Kepuasan atau rasa senang yang tinggi menciptakan ikatan emosional dengan merek atau perusahaan yang bersangkutan. Berdasarkan pendapat tersebut maka dapat diketahui bahwa kepuasan pelanggan berhubungan erat dengan dua hal yaitu harapan dan hasil yang diterima.

Kepuasan konsumen yaitu kesesuaian antara harapan dengan persepsi pelayanan yang diterima (hasil yang diperoleh atau kenyataan yang dialami). Kepuasan konsumen tercipta pada masa pembelian, pengalaman menggunakan produk atau jasa dan masa setelah pembelian. Konsumen yang merasa puas pada produk yang digunakannya akan kembali menggunakan produk yang ditawarkan. Hal ini mengakibatkan kepuasan konsumen merupakan salah satu faktor yang paling penting untuk memenangkan persaingan.

Setiap organisasi jasa yang berorientasi pada pelanggan wajib memberikan kesempatan seluas-luasnya bagi para pelanggannya untuk menyampaikan saran, kritik, pendapat, dan keluhan mereka. Media yang digunakan bisa berupa kontak saran yang diletakkan di tempat-tempat startegis (yang mudah diakses atau sering dilalui pelanggan), saluran telepon khusus bebas pulsa, sehingga memungkinkannya untuk bereaksi dengan tanggap dan cepat mengatasi masalahmasalah yang timbul.

Salah satu metode untuk memperoleh gambaran mengenai kepuasan pelanggan adalah dengan memeperkerjakan orang untuk berperan sebagai pelanggan potensial jasa perusahaan dan pesaing.

Perusahaan segyogyanya menghubungi para pelanggan yang telah berhenti membeli atau yang telah beralih pemasok agar dapat memahami mengapa hal itu terjadi dan supaya dapat mengambil kebijakan perbaikan atau penyempurnaan selanjutnya.

Umumnya sebagiaan besar penelitian mengenai kepuasan pelanggan menggunakan metode survei, baik via pos, telepon, e-mail, maupun wawancara langsung. Melalui survei perusahaan akan memperoleh tanggapan dan umpan balik langsung dari pelanggan danjuga memberikan sinyal positif bahwa perusahaan menaruh perhatian terhadap mereka.

Niat membeli dan sikap loyal dari konsumen adalah hal terpenting bagi sebuah perusahaan untuk mempertahankan eksistensinya 
dan agar dapat bertahan dalam persaingan dengan menjaga konsumen yang ada dan menarik perhatian konsumen baru. Perusahaan harus memberikan tingkat pelayanan yang baik dan tenaga kerja yang berkualitas supaya memberi kesan pengalaman positif kepada konsumen dan pada akhirnya dapat tercipta rasa kepuasan dan percaya (trust) dari konsumen terhadap perusahaan. Selanjutnya diharapkan dapat tercipta niat untuk membeli produk tersebut. Adji dkk. (2014) Minat beli ulang merupakan minat pembelian yang didasarkan atas pengalaman pembelian yang telah dilakukan di masa lalu. Dalam hal ini dapat dikatakan bahwa hasil dari pengalaman membeli sebelumnya sangat berpengaruh dengan pembelian selanjutnya. Jika pada pembelian pertama mendapatkan hasil yang memuaskan, konsumen akan mengalami minat pembelian ulang atau selanjutnya. Jika pembelian pertama memiliki hasil yang buruk, maka tidak aka nada pembelian selanjutnya atau pembelian ulang. Minat beli ulang yang tinggi mencerminkan tingkat kepuasan yang tinggi dari konsumen ketika memutuskan untuk membeli suatu produk Faradisa dkk. (2016)

Berdasarkan pengertian diatas dapat disimpulkan bahwa niat beli merupakan perasaan dalam diri seseorang yang mendorong terjadinya pembelian suatu produk atau jasa yang timbul karena mendapatkan informasi mengenai produk atau jasa tertentu. Niat beli yang terdapat pada diri seseorang untuk melakukan suatu perilaku dipengaruhi oleh sikap maupun variabel lainnya.

minat yang menggambarkan perilaku seseorang yang selalu mencari informasi mengenai produk yang dminatinya dan mencari informasi untuk mendukung sifat-sifat positif dari produk tersebut Menurut Corin et al. di kutip dalam Hendarsono dan Sugiharto (2013) pengertian minat beli ulang adalah perilaku pelanggan dimana pelanggan merespon positif terhadap apa yang telah diberikan oleh suatu perusahaan dan berminat untuk melakukan kunjungan kembali atau mengkomsusi kembali produk perusahaan tersebut. Menurut Fornell dalam Hendarsono dan Sugiharto (2013) mengatakan bahwa konsumen yang merasa puas akan melakukan kunjungan ulang di masa mendatang dan juga memberitahukan kepada orang lain atas produk atau jasa yang dirasakan.

Pengalaman berbelanja dan mengkonsumsi suatu produk tertentu akan memberikan dampak terhadap pengambilan keputusan seorang pelanggan apakah dia akan tetap menjalankan aktivitas belanjanya dengan cara tersebut atau beralih ke metode berbelanja yang lain. Suandana dkk. (2016), pengalaman yang menyenangkan dan memuaskan pada saat melakukan transaksi pembelian secara online berpengaruh positif pada niat mencari informasi dan niat membeli secara online di masa depan. Niat membeli ulang secara online merupakan situasi di mana pelanggan berkeinginan dan berniat untuk kembali melakukan transaksi online.Tidak ada dua pengalaman yang sama persis, melainkan ada berbagai pengalaman yang dirasakan berbeda Giantari dkk. (2013). Pengalaman membeli sebelumnya secara online berasosiasi positif dan signifikan dengan niat membeli kembali secara online, tidak hanya dipengaruhi oleh kepercayaan dan perilaku sosial Mohmed et al. (2013). Pengalaman membeli secara online memiliki pengaruh positif dan signifikan terhadap niat membeli kembali Parastanti dkk. (2014) 
$\mathrm{H}_{1}$ : Pengalaman berbelanja produk fashion berpengaruh positif dan signifikan terhadap niat membeli kembali.

Pentingnya pengalaman pelanggan untuk meningkatkan kinerja bisnis berarti bahwa retailer harus memahami bagaimana memastikan pengalaman pelanggan secara online yang baik secara optimal, sehingga dapat meningkatkan kepuasan pelanggan (Kerti yasa dkk., 2016). Pengalaman membeli secara online mempunyai pengaruh yang positif dan signifikan terhadap kepuasan pelanggan (Lin \&Lekhawipat, 2014; Wu \& Chang, 2007). Penelitian yang dilakukan Pramudita \& Japarianto (2013) menyatakan bahwa pengalaman membeli berpengaruh positif terhadap kepuasaan pelanggan.

$\mathrm{H}_{2}$ : Pengalaman berbelanja produk fashion berpengaruh positif dan signifikan terhadap kepuasan konsumen

Secara umum, Suandana dkk. (2016) menyatakan kepuasan adalah perasaan senang atau kecewa seseorang yang muncul setelah membandingkan kinerja/hasil produk yang dipikirkan terhadap kinerja/hasil yang diharapkan. Apabila kinerja berada di bawah harapan pelanggan, maka pelanggan tidak puas. Sebaliknya, jika kinerja memenuhi harapan pelanggan, maka pelanggan puas. Jika kinerja melebihi harapan pelanggan, maka pelanggan amat puas atau amat senang. Penelitian yang dilakaukan oleh Huang et al. (2014) didapatkan hasil kepuasan konsumen mempunyai efek positif dan signifikan pada niat membeli kembali. Telah banyak diteliti tentang kepuasan akan mempengaruhi niat beli ulang, Ini didukung oleh hasil penelitian (Yulianti dkk., 2014) yang menyatakan bahwa kepuasan berpengaruh signifikan dan sangat menyatakan bahwa secara keseluruhan, citra toko memiliki pengaruh yang signifikan dan sangat kuat terhadap kepuasan dan loyalitas, namun lebih kuat berpengaruh terhadap loyalitas, dimana pada penelitian ini niat beli ulang merupakan salah satu indikator loyalitas yang paling dipengaruhi.

$\mathrm{H}_{3}$ : Kepuasaan konsumen berpengaruh positif dan signifikan terhadap minat beli kembali

Kepuasan pelanggan adalah motivator untuk niat pembelian kembali. Pelanggan yang puas cenderung lebih menunjukkan kesetiaan atau loyalitas dibandingkan pelanggan yang tidak puas, salah satunya melalui pembelian ulang. Penelitian yang dilakukan oleh Kassim et al. (2014) menemukan bahwa kepuasan pelanggan memainkan peran penting dalam memediasi hubungan antara kualitas produk dan nilai yang dirasakan terhadap loyalitas merek. Kepuasan pelanggan sebagai mediator penting antara kualitas layanan yang dirasakan yang identik dengan pengalaman yang dirasakan terhadap loyalitas pelanggan (Suandana et al., 2016 ; Akbar \& Parvez, 2009),. Artinya, niat membeli kembali merupakan salah satu alat ukur loyalitas pelanggan. Penelitian yang dilakukan oleh Amini dkk. (2014) menunjukkan bahwa kepuasan dan kepercayaan dari konsumen memiliki pengaruh positif terhadap minat beli ulang. Penelitian sebelumnya telah 
memberikan empiris dukungan untuk efek pengalaman pada hubungan antara kepuasan pelanggan dan niat untuk membeli kembali Pappas et al. (2014)

$\mathrm{H}_{4}$ : Kepuasaan konsumen mampu memediasi pengaruh pengalaman berbelanja terhadap minat beli kembali

Berdasarkan paparan latar belakang diatas maka didapat rumusan masalah sebagai berikut: Bagaimana pengaruh pengalaman berbelanja terhadap minat beli kembali? Bagaimana pengaruh pengalaman berbelanja terhadap kepuasan konsumen? Bagaimana pengaruh kepuasan konsumen terhadap minat beli kembali? Apakah kepuasaan mampu memediasi pengaruh pengalaman berbelanja terhadap minat beli kembali?

Tujuan Penelitian berdasarkan rumusan masalah diatas adalah sebagai berikut: Untuk menjelaskan pengaruh pengalaman brbelanja terhadap minat beli kembali. Untuk menjelaskan pengaruh pengalaman berbelanja terhadap kepuasan konsumen. Untuk menjelaskan pengaruh kepuasan konsumen terhadap minat beli kembali. Untuk menjelaskan pengaruh peran kepuasan konsumen memediasi pengalaman berbelanja terhadap minat beli kembali .

Berdasarkan latar belakang, rumusan masalah, tujuan penelitian dan kajian pustaka, berikut ditampilkan kerangka konseptual penelitian ini :

\section{Gambar 2. Kerangka Konseptual}

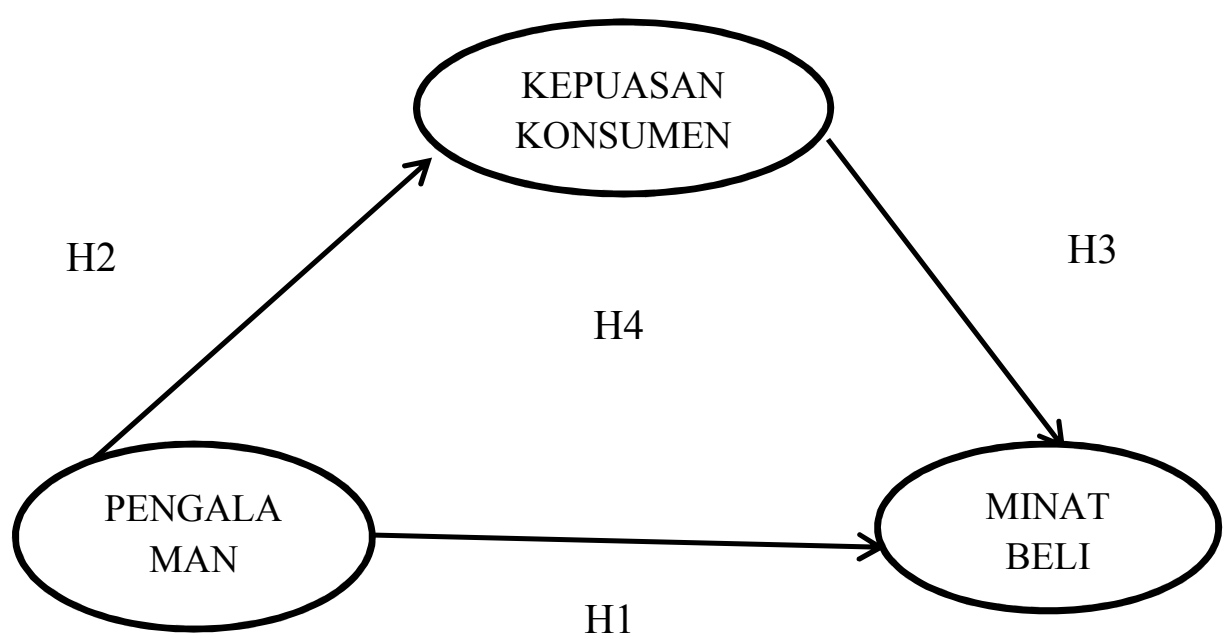

\section{METODE PENELITIAN}

Lokasi penelitian yang dipilih oleh peneliti terletak di Bali. Pada penelitian ini, penulis memilih Bali sebagai lokasi penelitian karena Bali memiliki outletoutlet produk fashion global serta masyarakat bali yang memiliki pendapatan yang tinggi. 
Populasi dalam penelitian ini adalah konsumen Fashion merk ZARA. Teknik penentuan sampel yang digunakan dalam penelitian ini adalah non probability sampling, Teknik non probability sampling yang dipilih adalah purposive sampling yaitu teknik penentuan sampel dengan pertimbangan tertentu.

Model empiris dan hipotesis diuji menggunakan analisis statistik inferensial dengan teknik analisisnya adalah model persaman structural (Structural Equation Modeling/SEM). SEM yang digunakan berbasis variance atau yang sering disebut dengan Partial Least Square (PLS).

\section{HASIL DAN PEMBAHASAN}

Zara didirikan oleh Amancio Ortega, juga penemu dari inditex yang memperkenalkan fashion dengan menawarkan busana dengan tren terbaru namun harga relatif terjangkau. Hal ini terinspirasi ketika ia berada di depan toko pakaian yang terletak di pelabuhan La coruna dan ia merasakan pergerakan fashion yang monoton dimana pakaian yang ditawarkan hanya berdasarkan selera produsen. Sementara konsumen sebagai pemakai produk fashion tersebut tidak dapat menjadi dirinya sendiri dan tidak dapat memilih fashion yang ingin digunakan sedangkan harus membayar dengan harga yang sangat mahal. Selain itu, Amancio Ortega sadar hanya sedikit orang kaya yang mampu membeli baju-baju dengan harga mahal, bersama saudara dan istrinya Amancio mulai memproduksi baju murah namun berkualitas bagus. Pada tahun 1975 gerai pertamanya didirikan di La Coruna di depan pusat perbelanjaan paling penting di Spanyol, bisnisnya berkembang pesat karena harganya yang murah dan kualitasnya yang mewah. Pada tahun 1980an, ortega telah melakukan ekspansi domestik yang telah membuka hampir 100 toko Zara di Spanyol dan ekspansi internasional pertamanya didirikan di Portugal. Hingga saat ini terdapat lebih dari 1.700 toko Zara di 86 negara yang tersebar di enam benua.

Zara pertama kali masuk ke indonesia di bawah bendera MAP Group ( PT. Mitra Adi Perkasa Tbk.) pada 18 agustus 2008. MAP merupakan peritel terkemuka di Indonesia yang saat ini memiliki lebih dari 2000 toko ritel yang tersebar di 66 kota meliputi produk fashion, sports, departerment store, anakanak, makanan dan minuman, produk lifestyle, dan sebagainya. MAP juga menjadi distributor sejumlah merk terkenal yang tidak asing dengan keseharian kita seperti Nike, Nine West, Oakley, Reebok, Adidas, New Balance dan lainlain. Untuk Produk Zara, MAP mendatangkanya langsung dari Spanyol dengan model pembelian sistem putus, dimana produk yang tidak terjual menjadi tanggungan Zara di Indonesia sendiri. Dengan berdirinya Zara di Indonesia MAP mendaptakan respon positif dari Konsumen melalui produk dan suasana gerainnyayang ekslusif. Saat ini sudah berdiri 13 gerai Zara yang tersebar di Jakarta, Bandung, Surabaya, dan yang terkini di Bali.

Sebanyak 43 responden adalah pria dan sebanyak 52 responden adalah wanita. Usia responden di dominasi dengan usia $>18-24$ tahun sebanyak 84 orang, usia $>24-30$ sebanyak 6 orang dan Usia $>36$ tahun sebanyak 5 orang. Dapat disimpulkan bahwa rata-rata usia responden terbanyak berasal dari golongan usia $>18-24$ tahun. Tingkat pendidikan terakhir responden terbanyak yaitu Sarjana (S1) sebanyak 48 orang, SMA sebanyak 42 orang dan Magister (S2) 
sebanyak 5 orang. Anggaran konsumen dalam sekali belanja produk fashion dari $<$ Rp. 600,000 sebanyak 20 responden, > Rp. 600,000 - Rp.1,200,000 sebanyak 53 responden, $>$ Rp. 1,200,000 - Rp. 1,800,000 sebanyak 12 responden dan $>$ Rp. 1,800,000 sebanyak 11 responden.

Dari 95 responden Rata-rata responden berdomisil di dalam kota dengan jumlah 79 responden sedangkan yang berdomisil di pinggir kota sebanyak 10 responden dan yang berada di luar kota sebanyak 6 responden. Responden dalam penelitian ini mengetahui beberapa merk fashion global selain Zara, responden penelitian ini banyak yang memiliki frekuensi berbelanja produk fashion tertinggi sekitar 1-3 kali dalam 30 hari sebesar 57,9 persen, kemudian frekuensi sekitar 1-3 dalam 60 hari sebesar 26,3 persen dan 7,4 persen untuk frekuensi berbelanja produk fashion terendah sekitar 1-3 dalam 90 hari dan yang terakhir frekuensi berbelanja produk fashion yang dilakukan responden sekitar 1-3 >90 hari sebesar 8,4 persen. Sebanyak 89,5 responden mengikuti trend fashion terbaru sebelum berbelanja sedangkan 10,5 persen responden tidak mengikuti trend fashion sebelum berbelanja produk fashion.

Sebesar 81,1 persen responden merasa fashion sangat penting untuk citra diri mereka sedangkan sebesar 17,9 persen responden merasa fashion tidak terlalu penting namun mereka perlu mengikuti fashion dan sebesar 1,1 persen responden menyatakan fashion tidak penting untuk citra dirinya. Pengalaman berbelanja mampu meningkatkan kepuasaan konsumen, sebesar 83,2 responden menyatakan pengalaman berbelanja mereka sungguh menyenangkan kemudian sebesar 4,2 responden menyatakan pengalaman berbelanja mereka sunggguh menggairahkan, namun sebesar 4,2 persen responden menyatakan bahwa pengalaman berbelanja mereka sungguh melelahkan dan sebesar 1,1 persen responden menyatakan bahwa pengalaman berbelanja mereka sunggguh membosankan.

Variabel niat beli kembali diukur dengan 4 indikator. Hasil tanggapan responden diuraikan pada tabel 1 .

Tabel 1.

Deskripsi Variabel Minat Beli Kembali

\begin{tabular}{ccccccccc}
\hline Indikator & \multicolumn{9}{c}{ Skor Jawaban } & & Jumlah Skor & Rata-Rata & Keterangan \\
\hline & $\mathbf{1}$ & $\mathbf{2}$ & $\mathbf{3}$ & $\mathbf{4}$ & $\mathbf{5}$ & & & \\
\hline Minat Transaksional & 0 & 0 & 25 & 36 & 34 & 389 & 4.09 & Tinggi \\
Minat Referensial & 0 & 1 & 28 & 36 & 30 & 380 & 4.00 & Tinggi \\
Minat Prefensial & 0 & 5 & 20 & 41 & 29 & 379 & 3.99 & Tinggi \\
Minat Eksploratif & 2 & 5 & 23 & 36 & 29 & 370 & 3.89 & Tinggi \\
\hline \multicolumn{10}{c}{ Y2 } & & & $\mathbf{3 . 9 9}$ & Tinggi \\
\hline
\end{tabular}

Sumber : Data diolah, 2018

Tabel 1. menunjukan bahwa 4 (empat) pernyataan indikator mengenai niat beli kembali memperoleh nilai rata-rata sebesar 3.99 yang masuk dalam kategori penilaian tinggi sehingga tabel diatas menunjukan bahwa tingginya niat beli kembali yang dilakukan konsumen pada produk fashion Zara.

Variabel kepuasaan pada penelitian ini diukur oleh 4 indikator dengan hasil tanggapan responden diuraikan pada Tabel 2. 
Tabel 2.

Deskripsi Variabel Kepuasaan Konsumen

\begin{tabular}{|c|c|c|c|c|c|c|c|c|}
\hline \multirow[t]{2}{*}{ Indikator } & \multicolumn{5}{|c|}{ Skor Jawaban } & \multirow[t]{2}{*}{$\begin{array}{l}\text { Jumlah } \\
\text { Skor }\end{array}$} & \multirow[t]{2}{*}{$\begin{array}{l}\text { Rata- } \\
\text { Rata }\end{array}$} & \multirow[t]{2}{*}{$\begin{array}{c}\text { Keteranga } \\
\text { n }\end{array}$} \\
\hline & 1 & 2 & 3 & 4 & 5 & & & \\
\hline Re-purchase & 1 & $\begin{array}{l}1 \\
3\end{array}$ & $\begin{array}{l}1 \\
5\end{array}$ & $\begin{array}{l}4 \\
1\end{array}$ & 25 & 361 & 3.80 & Tinggi \\
\hline Word of Mouth & 0 & 9 & $\begin{array}{l}1 \\
7\end{array}$ & $\begin{array}{l}4 \\
4\end{array}$ & 25 & 370 & 3.89 & Tinggi \\
\hline Citra Merek & 0 & 1 & $\begin{array}{l}3 \\
0\end{array}$ & $\begin{array}{l}3 \\
8\end{array}$ & 26 & 374 & 3.94 & Tinggi \\
\hline $\begin{array}{l}\text { Menciptakan keputusan } \\
\text { pembelian }\end{array}$ & 0 & 1 & $\begin{array}{l}2 \\
2\end{array}$ & $\begin{array}{l}4 \\
5\end{array}$ & 27 & 383 & 4.03 & Tinggi \\
\hline & Y1 & & & & & & 3.92 & Tinggi \\
\hline
\end{tabular}

Sumber : Data diolah, 2018

Tabel 2. menunjukan bahwa 4 (empat) pernyataan indikator mengenai kepuasaan memperoleh nilai rata - rata sebesar 3.92 yang masuk dalam kategori penilaian tinggi. Hal ini menunjukan bahwa tingginya kepuasaan konsumen produk fashion Zara.

Variabel pengalaman berbelanja pada penelitian ini diukur oleh 12 indikator dengan hasil tanggapan responden diuraikan pada tabel 3.

Tabel 3. menunjukan bahwa 12 (dua belas) pernyataan indikator mengenai pengalaman berbelanja memperoleh nilai rata - rata sebesar 4.00 yang masuk dalam kategori penilaian tinggi. Hal ini menunjukan bahwa konsumen produk fashion zara merasakan pengalaman berbelanja yang baik.

Tabel 3.

Deskripsi Variabel Pengalaman Berbelanja

\begin{tabular}{|c|c|c|c|c|c|c|c|c|}
\hline \multirow[t]{2}{*}{ Indikator } & \multicolumn{5}{|c|}{ Skor Jawaban } & \multirow[t]{2}{*}{ Jumlah Skor } & \multirow[t]{2}{*}{ Rata-Rata } & \multirow[t]{2}{*}{ Keterangan } \\
\hline & 1 & 2 & 3 & 4 & 5 & & & \\
\hline Hedonistic & 0 & 2 & 24 & 42 & 27 & 379 & 3.99 & Tinggi \\
\hline Pelarian dari masalah & 0 & 5 & 28 & 45 & 17 & 359 & 3.78 & Tinggi \\
\hline Pengikut & 1 & 8 & 22 & 42 & 22 & 361 & 3.80 & Tinggi \\
\hline Tantangan & 0 & 1 & 17 & 36 & 41 & 402 & 4.23 & Tinggi \\
\hline Pembelajaran & 0 & 4 & 24 & 38 & 29 & 377 & 3.97 & Tinggi \\
\hline Interaksi Sosial & 0 & 4 & 15 & 43 & 33 & 390 & 4.11 & Tinggi \\
\hline Komunitas & 0 & 5 & 18 & 39 & 33 & 385 & 4.05 & Tinggi \\
\hline Musik & 1 & 3 & 28 & 38 & 25 & 368 & 3.87 & Tinggi \\
\hline Tata Letak & 0 & 3 & 24 & 39 & 29 & 379 & 3.99 & Tinggi \\
\hline Karyawan & 0 & 5 & 23 & 38 & 29 & 376 & 3.96 & Tinggi \\
\hline Pencahayaan & 0 & 1 & 22 & 40 & 32 & 388 & 4.08 & Tinggi \\
\hline Layout & 0 & 1 & 19 & 36 & 39 & 398 & 4.19 & Tinggi \\
\hline \multicolumn{6}{|c|}{$X$} & & 4.00 & Tinggi \\
\hline
\end{tabular}

Sumber : Data diolah, 2018 
Tabel 4.

Validitas Indikator-Indikator Minat beli kembali(Y2), Kepuasan (Y1), dan Pengalaman Berbelanja (X)

\begin{tabular}{|c|c|c|c|}
\hline $\begin{array}{l}\text { Indikato } \\
\mathbf{r}\end{array}$ & Outer loading & $\begin{array}{c}\text { Composite } \\
\text { Reliability } \\
\text { (CR) }\end{array}$ & $\begin{array}{c}\text { Average } \\
\text { Variance Extracted } \\
(A V E)\end{array}$ \\
\hline Y1.1 & 0,770 & & \\
\hline Y1.2 & 0,825 & 0,898 & ‘ 0,688 \\
\hline Y1.3 & 0,894 & & \\
\hline Y1.4 & 0,824 & & \\
\hline Y2.1 & 0,834 & & \\
\hline $\mathrm{Y} 2.2$ & 0,898 & 0,920 & 0,743 \\
\hline Y2.3 & 0,867 & & \\
\hline Y 2.4 & 0,847 & & \\
\hline $\mathrm{X} 1$ & 0,793 & & \\
\hline $\mathrm{X} 2$ & 0,705 & & \\
\hline $\mathrm{X} 3$ & 0,770 & & \\
\hline $\mathrm{X} 4$ & 0,789 & & \\
\hline $\mathrm{X} 5$ & 0,852 & 0,947 & 0,598 \\
\hline X6 & 0,749 & & \\
\hline $\mathrm{X} 7$ & 0,818 & & \\
\hline $\mathrm{X} 8$ & 0,702 & & \\
\hline X9 & 0,795 & & \\
\hline $\mathrm{X} 10$ & 0,784 & & \\
\hline X11 & 0,738 & & \\
\hline $\mathrm{X} 12$ & 0,773 & & \\
\hline
\end{tabular}

Sumber: Data diolah, 2018

Tabel 4. menunjukan bahwa outer loading seluruh indikator pada masingmasing variabel diatas bernilai diatas 0.6 yang artinya sesuai dengan ketentuan seluruh indikator yang membentuk variable laten dapat dikatakan valid, kemudian nilai composite reliability (CR) seluruh variabel telah berada di atas 0,6 yang berarti seluruh variabel sudah reliabel

Evaluasi Discriminant validity dapat dilakukan dengan membandingkan nilai akar AVE dari setiap indikator yang membentuk variabel laten. Apabila nilai akar AVE dari setiap variabel diagonal lebih besar dari pada variabel bukan diagonal, maka discriminant validity dikatakan baik.

Tabel 5.

Corelations of Constructs

\begin{tabular}{cccc}
\hline Variabel Laten & Kepuasaan & Minat beli kembali & $\begin{array}{c}\text { Pengalaman } \\
\text { berbelanja }\end{array}$ \\
\hline Kepuasan & $\mathbf{0 , 8 2 9}$ & & \\
Minat Beli Kembali & 0,697 & $\mathbf{0 , 8 6 2}$ & $\mathbf{0 , 7 7 3}$ \\
\hline Pengalaman Berbelanja & 0,676 & 0,710 &
\end{tabular}


Tabel 4. menunjukkan bahwa nilai akar AVE diagonal dari setiap indikkator yang membentuk variabel laten lebih besar dari pada variabel non bukan diagonalnya, sehingga evaluasi discriminant validitynya dikatakan baik.

Evaluasi Discriminant validity dapat dilakukan dengan membandingkan nilai akar AVE dari setiap indikator yang membentuk variabel laten. Apabila nilai akar AVE dari setiap variabel diagonal lebih besar dari pada variabel bukan diagonal, maka discriminant validity dikatakan baik.

Tabel 6.

Corelations of Constructs

\begin{tabular}{cccc}
\hline Variabel Laten & Kepuasaan & $\begin{array}{c}\text { Minat beli } \\
\text { kembali }\end{array}$ & $\begin{array}{c}\text { Pengalama } \\
\text { n berbelanja }\end{array}$ \\
\hline $\begin{array}{c}\text { Kepuasan } \\
\text { Minat Beli } \\
\text { Kembali } \\
\begin{array}{c}\text { Pengalaman } \\
\text { Berbelanja }\end{array}\end{array}$ & $\mathbf{0 , 8 2 9}$ & & \\
\hline
\end{tabular}

Sumber: Data diolah, 2018

Tabel 6. menunjukkan bahwa nilai akar AVE diagonal dari setiap indikkator yang membentuk variabel laten lebih besar dari pada variabel non bukan diagonalnya, sehingga evaluasi discriminant validitynya dikatakan baik.

Suatu model struktural dapat digunakan untuk mengambil kesimpulan tentang hubungan antar variabel laten bebas berkorelasi terhadap variabel laten terikatnya dan memberikan penjelasan mengenai prediksi dari model yang diajukan untuk di teliti. Model struktural dalam suatu penelitian berfokus pada jalur antar variabel latennya ( Hair et al., 2014), dalam evaluasi struktural pada penelitian ini dimulai dengan nilai $\mathrm{t}$ (t-test) dan $\mathrm{R}^{2}$ yang dapat didefinisikan seperti regresi berganda (multiple regression). Tabel 4.9 menunjukan nilai $\mathrm{R}^{2}$.

Tabel 7.

Nilai $R$-square

\begin{tabular}{cc}
\hline Konstruk & Nilai R $^{\mathbf{2}}$ \\
\hline Kepuasan & 0,457 \\
Minat beli & 0,590 \\
\hline
\end{tabular}

Sumber : Data diolah, 2018

Tabel 7. diatas menunjukan nilai $\mathrm{R}^{2}$ kepuasaan dan minat belinya memiliki rentangan dari 0,457 hingga 0,590 . Minat beli memiliki nilai $\mathrm{R}^{2}$ tertinggi yaitu sebesar 0,590 yang dapat diartikan bahwa sebanyak 59 persen variabel minat beli dapat dijelaskan oleh variabel yang terdapat dalam model yaitu variabel kepuasaan dan variabel pengalaman berbelanja, sedangkan variabel kepuasaan memiliki nilai $\mathrm{R}^{2}$ terendah sebesar 0,457 yang berarti bahwa sebesar 45,7 persen variabel kepuasan dapat didefinisikan oleh variabel yang mempengaruhinya yaitu pengalaman berbelanja.

Pengujian Hipotesis dalam penelitian ini tentang pengaruh pengalaman berbelanja, kepuasaan dan minat beli kembali. Untuk membuktikan signifikansi hubungan konstruk dan mendukung hipotesis yang telah dibangun dapat dilihat dari nilai t-value (t-statistic) dengan signifikansi sebesar 0,05 atau lebih besar dari 
1,96. Pengujian hipotesis yang dilakukan dengan PLS menggunakan metode bootstrape untuk menguji korelasi antara variabel sesuai hipotesis dan kriteria yang telah disajikan diatas untuk mengevaluasi hasil dari pengolahan data. Tabel 4 memaparkan hasil uji yang menampilkan nilai koefisien t-value terhdap hipotesisnya.

\section{Tabel 8.}

Hasil Path Coefficient metode PLS

\begin{tabular}{|c|c|c|c|c|}
\hline $\begin{array}{l}\text { Hipotesi } \\
\text { s }\end{array}$ & HubunganAntarVariabel & $\begin{array}{l}\text { Path } \\
\text { Coefficien } \\
t\end{array}$ & $\begin{array}{l}T- \\
\text { Statistics }\end{array}$ & $\begin{array}{l}\text { Keterang } \\
\text { an }\end{array}$ \\
\hline H1 & Kepuasaan $\rightarrow$ Minat beli kembali & 0,399 & 3,495 & signifikan \\
\hline $\mathrm{H} 2$ & Pengalaman berbelanja $\rightarrow$ Kepuasaan & 0,676 & 10,581 & signifikan \\
\hline $\mathrm{H} 3$ & $\begin{array}{l}\text { Pengalaman berbelanja } \rightarrow \text { Minat beli } \\
\text { kembali }\end{array}$ & 0,440 & 3,554 & signifikan \\
\hline $\mathrm{H} 4$ & $\begin{array}{l}\text { Pengalaman berbelanja } \rightarrow \text { Kepuasaan } \\
\rightarrow \text { Minat beli kembali }\end{array}$ & 0,270 & 2,943 & Signifikan \\
\hline
\end{tabular}

Sumber : Data diolah, 2018

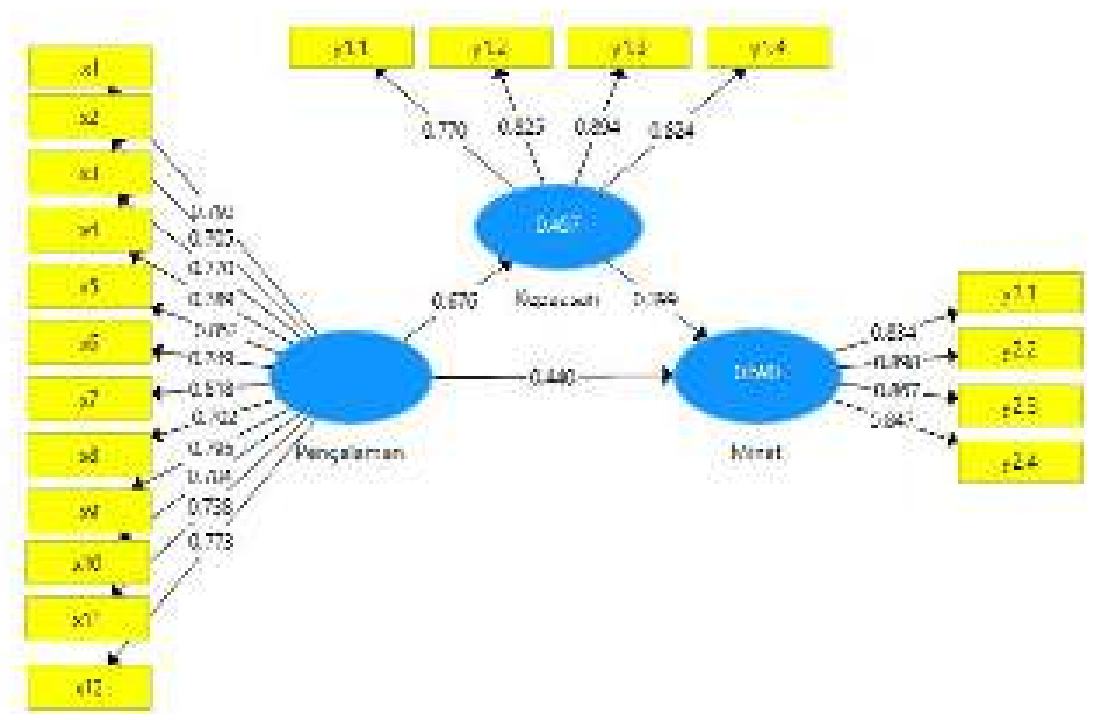

Gambar 3. Diagram Jalur Variabel Minat beli kembali (Y2), Kepuasan Konsumen (Y1) dan Pengalaman Berbelanja (X)

Tabel 9. Hasil Indirect Effect Metode PLS

\begin{tabular}{lccc}
\multicolumn{1}{c}{ Hubungan Antar Variabel } & $\begin{array}{c}\text { Path } \\
\text { Coefficient }\end{array}$ & $\begin{array}{c}\text { T- } \\
\text { statistik }\end{array}$ & keterangan \\
\hline $\begin{array}{l}\text { Pengalaman berbelanja } \rightarrow \text { Kepuasaan } \rightarrow \text { Minat } \\
\text { beli kembali }\end{array}$ & 0,270 & 2,943 & signifikan \\
\hline Sumber : Data primer diolah,2018. & & &
\end{tabular}

Pada penelitian ini, hasil pengujian hipotesis pada kepuasaan terhadap minat beli kembali produk fashion Zara di wilayah Bali menunjukan bahwa nilai path 
coefficientsyang positif sebesar 0,399 dan signifikan $\alpha=5$ persen ( $\mathrm{t}$-value 3,495 $>1,96$ ). Hal ini menunjukan bahwa kepuasaan berpengaruh positif dan signifikan terhadap minat beli kembali. Berdasarkan hal tersebut maka hipotesis kepuasaan berpengaruh positif dan signifikan terhadap minat beli kembali produk fashion Zara di wilayah Bali dapat di terima. Sehingga dapat disimpulkan bahwa semakin tinggi kepuasaan yang dirasakan konsumen semakin tinggi minat beli kembali produk fashionZara di wilayah Bali.

Hasil uji hipotesis penelitian ini sejalan dengan hasil penelitian terdahulu yang dilakukan oleh Suandana dkk. (2016), Huang et al. (2014), Yulianti dkk. (2014) yang menyimpulkan bahwa kepuasaan berpengaruh positif dan signifikan terhadap minat beli kembali.

Pada penelitian ini, hasil pengujian hipotesis pada pengalaman berbelanja terhadap kepuasaan produk fashion Zara di wilayah Bali menunjukan bahwa nilai path coefficients yang positif sebesar 0,676 dan signifikan $\alpha=5$ persen ( $\mathrm{t}$-value 10,581> 1,96). Hal ini menunjukan bahwa pengalaman berbelanja positif dan signifikan terhadap kepuasaan. Berdasarkan hal tersebut maka hipotesis pengalaman berbelanja berpengaruh positif dan signifikan terhadap kepuasan konsumen produk fashion Zara di wilayah Bali dapat di terima. Sehingga dapat disimpulkan bahwa semakin baik pengalaman berbelanja yang dibentuk oleh perusahaan semakin tinggi kepuasan yang dirasakan konsumen produk fashionZara di wilayah Bali.

Hasil uji hipotesis penelitian ini sejalan dengan hasil penelitian terdahulu yang dilakukan oleh Kerti yasa dkk. (2016), (Lin \&Lekhawipat, 2014; Wu \& Chang, 2007) dan Pramudita \& Japarianto (2013) yang menyimpulkan bahwa pengalaman berbelanja berpengaruh positif dan signifikan terhadap kepuasaan.

Pada penelitian ini, hasil pengujian hipotesis pada pengalaman berbelanja terhadap minat beli kembali produk fashion Zara di wilayah Bali menunjukan bahwa nilai path coefficients yang positif sebesar 0,676 dan signifikan $\alpha=5$ persen ( $\mathrm{t}$-value 10,581>1,96). Hal ini menunjukan bahwa pengalaman berbelanja positif dan signifikan terhadap minat beli kembali. Berdasarkan hal tersebut maka hipotesis pengalaman berbelanja berpengaruh positif dan signifikan terhadap minat beli kembali produk fashion Zara di wilayah Bali dapat di terima. Sehingga dapat disimpulkan bahwa semakin baik pengalaman berbelanja yang dibentuk perusahaan semakin tinggi terjadinya minat beli kembali pada konsumen produk fashion Zara di wilayah Bali.

Hasil uji hipotesis penelitian ini sejalan dengan hasil penelitian terdahulu yang dilakukan oleh Suandana dkk. (2016), Giantari dkk. (2013), (Mohmed et al., 2013; Weisberg et al., 2011) dan (Thamizhvanan \& Xavier, 2013) yang menyimpulkan bahwa pengalaman berbelanja berpengaruh positif dan signifikan terhadap kepuasaan.

Hasil pengujian hipotesis mengenai peran kepuasan dalam memediasi pengaruh pengalaman berbelanja terhadap minat beli kembali memperlihatkan bahwa kepuasan memediasi pengaruh pengalaman berbelanja terhadap minat beli kembali berpengaruh positif dan signifikan. Hal ini memiliki makna bahwa semakin tinggi kepuasan yang dirasakan konsumen maka pengalam berbelanja yang dirasakan konsumen juga akan meningkat sehingga minat beli kembali 
konsumen akan meenjadi tinggi. Hasil penelitian ini sesuai dengan hasil penelitian yang dilakukan oleh Kassim et al. (2014), Suandana et al. (2016) ; Akbar \& Parvez, (2009), Amini dkk. (2014) dan (Pappas et al., 2014;Khalifa and Liu, 2007) yang menyimpulkan bahwa kepuasan memediasi pengaruh pengalaman berbelanja terhadap minat beli kembali.

Dalam penelitian ini pengalaman berbelanja memiliki pengaruh khusus dalam situasi lingkungan toko (yaitu fitur fisik dan sosial) yang dapat memicu kepuasan konsumen. Suasana yang dapat membangkitkan kepuasaan konsumen adalah situasi lingkungan toko yang memiliki penataan produk yang menarik, kelengkapan produk, pencahayaan toko yang sesuai dan memiliki layout yang memudahkan pelanggan untuk berkeliling.Pengalaman berbelanja memiliki pengaruh yang lebih besar karena dalam proses berbelanja dapat memberikan pengalaman yang memuaskan baik dari segi emosi maupun pikiran, perusahaan harus memperhatikan karakteristik toko yang dapat memberikan tanggapan secara terbuka antara harapan dan persepsi agar setiap konsumen memiliki kebebasan untuk melakukan pembelian. Jika di dalam benak konsumen sudah mendapatkan pengalaman berbelanja yang memuaskan terciptalah kepuasan pelanggan (Herabadi et al., 2009). Sehingga dapat dikatakan bahwa pengaruh positif pengalaman berbelanja terhadap kepuasaan lebih besar dari pada pengaruh positif kepuasaan terhadap minat beli kembali. Hal ini dikarenakan pengalaman berbelanja yang dibentuk oleh perusahaaan sangat baik sehingga konsumen merasakan kepuasaan yang tinggi sedangkan kepuasaan konsumen belum tentu menimbulkan minat beli kembali karena minat beli terjadi di masa depan.

Penelitian ini hanya bisa dilakukan pada responden produk fashion Zara Beachwalk yang melibatkan responden dengan jumlah terbatas yaitu 95 responden yang merupakan konsumen dari produk fashion Zara Beachwalk sehingga masih dirasa perlu untuk melakukan penelitian dengan topik serupa pada lokasi dan jumlah responden yang lebih besar.

Penelitian ini hanya meneliti sebatas pada tiga variabel saja yaitu, minat beli kembali, kepuasan, pengalaman berbelanja. Diharapkan pada penelitian selanjutnya dapat mengembangkan lagi variabel yang diteliti mengingat terdapat banyak variabel-variabel lain yang mempengaruhi minat beli kembali.

\section{SIMPULAN}

Kepuasaan berpengaruh positif dan signifikan terhadap minat beli kembali pada konsumen produk fashion Zara di wilayah Bali. Hal ini menunjukan bahwa semakin tinggi kepuasaan yang dirasakan konsumen semakin tinggi minat beli kembali produk fashion Zara di wilayah Bali

Pengalaman berbelanja positif dan signifikan terhadap kepuasaan pada konsumen produk fashion Zara di wilayah Bali. Hal ini menunjukan bahwa semakin baik pengalaman berbelanja yang dibentuk oleh perusahaan semakin tinggi kepuasan yang dirasakan konsumen produk fashion Zara di wilayah Bali.

Pengalaman berbelanja positif dan signifikan terhadap minat beli kembali kepuasaan pada konsumen produk fashion Zara di wilayah Bali. Hal ini menunjukan bahwa semakin baik pengalaman berbelanja yang dibentuk 
perusahaan semakin tinggi terjadinya minat beli kembali pada konsumen produk fashion Zara di wilayah Bali. Kepuasan memediasi pengaruh pengalaman berbelanja terhadap minat beli kembali berpengaruh secara positif dan signifikan. Hal ini memiliki makna bahwa semakin tinggi kepuasan yang dirasakan konsumen maka pengalam berbelanja yang dirasakan konsumen juga akan meningkat sehingga minat beli kembali konsumen akan menjadi tinggi.

Manajemen Zara perlu menarik perhatian konsumen dengan berbagai cara dan memberikan fasilitas - fasilitas penunjang mengenai informasi produknya agar konsumen selalu mengikuti informasi mengenai fashion terbaru yang ditawarkan oleh Zara. Kepuasaan konsumen Zara dapat dijaga dengan selalu menawarkan trend fashion terbaru agar sesuai dengan keinginan konsumen dan selalu melakukan peningkatan kualitas serta pelayanan yang diberikan untuk konsumen sehingga konsumen menjadi loyal terhadap perusahaan.

Manajemen Zara diharapkan mampu memenuhi kebutuhan konsumen dengan memperbanyak persediaan pada produknya serta manajemen diharapkan mampu memberikan pilihan lain yang dapat menunjukan citra diri dari konsumen tersebut.

\section{REFERENSI}

Adji, J., Hatane, D., \& Siwalankerto, J. (2014). Pengaruh Satisfaction Dan Trust Terhadap Minat Beli Konsumen ( Purchase Intention ) Di Starbucks The Square Surabaya. Jurnal Manajemen Pemasaran Petra, 2(1), 1-10.

Alwafi, Fachrizi., dan Magnadi, R. H. (2016). Pengaruh Persepsi

Keamanan,Kemudahan Bertransaksi,Kepercayaan Terhadap Toko dan Pengalaman Berbelanja Terhadap Minat Beli Secara Online Pada Situs Jual Beli Tokopedia.com. Diponegoro Journal of Management, 5(2), 1-15.

Amini, Mohammad., dan Akbari, H. (2014). Studying Effevt Of Site Quality On Online Repurchase Intention Through Satisfaction, Trust And Commitment Of Customer. Indian Journal of Fundamental and Applied Life Science, 4(S4), 2839-2849.

Arina, Y., Japarianto, E., Pemasaran, J. M., Petra, U. K., \& Siwalankerto, J. (2013). Analisa Pengaruh Customer Value dan Customer Experience terhadap Customer Satisfaction di De Kasteel Resto Surabaya. Jurnal Manajemen Pemasaran Petra, 1(1), 1-7.

Artiningtyas,Indah.,Minarsih,Maria M.,dan Hasiolan, L. B. (2015). Pengaruh Kualitas Layanan,Persepsi Harga Dan Kepercayaan Terhadap Kepuasan Pelanggan ( Studi Kasus Pada Toko Vulkanisir Ban Top Cool Semarang). Journal of Management, 1(1), 1-13.

Ayu, I. G., Giantari, K., Zain, D., \& Rahayu, M. (2013). The role of perceived behavioral control and trust as mediator of experience on online purchasing intentions relationship a study on youths in denpasar city ( Indonesia ). International Journal of Business and Management Invention, 2(1), 30-38. 
Faradisa, Isti., H, Budi Leonardo., Minarsih, M. M. (2016). Analisis Pengaruh Variasi Produk, Fasilitas, Dan Kualitas Pelayanan Terhadap Minat Beli Ulang Konsumen Pada Indonesia Coffeeshop Semarang ( ICOS CAFE). Journal of Management, 2(2).

Hendarsono, G., Pemasaran, J. M., Petra, U. K., \& Siwalankerto, J. (2013). Analisa pengaruh experiential marketing terhadap minat beli ulang konsumen cafe buntos 99 sidoarjo. Jurnal Manajemen Pemasaran, 1(2), 1-8.

Lichtl, Marie-christine., Plichon, V. (2014). Emotions experienced in retail outlets: A proposed measurement scale. Recherche et Applications En Marketing, 29(1). https://doi.org/10.1177/2051570714524880

Lin, Chinho., Lekhawipat, W. (2014). Factors affecting online repurchase intention. Industrial Management \& Data System, 114(4), 597-611. https://doi.org/10.1108/IMDS-10-2013-0432

Marques, S. H., \& Cardoso, M. M. (2013). The International Review of Retail, Distribution and Consumer Research. The International Review of Retail,Distribution and Consumer Research, 23(4), 456-474. https://doi.org/10.1080/09593969.2013.785442

Mohmed, S. I., Azizan, B., \& Jali, Z. (2013). The Impact of Trust and Past Experience on Intention to Purchase in E-Commerce. International Journal of Engineering Research and Development, 7(10), 28-35.

Pappas, I. O., Pateli, A. G., Giannakos, M. N., \& Chrissikopoulos, V. (2014). Moderating effects of online shopping experience on customer satisfaction and repurchase intentions. International Journal of Retail \& Distribution Management, 42(3), 187-204. https://doi.org/10.1108/IJRDM-03-2012-0034

Parastanti, Gadis Paramita., Kumadji, Srikandi., dan Hidayat, K. (2014). Pengaruh Prior Online Purchase Experience Terhadap Trust Dan Online Repurchase Intention ( Survey pada Pelanggan ZALORA Indonesia Melalui Website www.zalora.co.id). Jurnal Administrasi Bisnis, 16(1).

Pujiati, S. S., Haryono, A. T., \& Paramita, P. D. (2016). Faktor - Faktor Yang Mempengaruhi Loyalitas Pelanggan Pada Ahyana Collections Dengan Minat Beli Ulang Sebagai Variabel Intervening. Journal of Management, 02(02).

Putu, N., Suandana, W., \& Rahyuda, Ketut., dan Kerti yasa, N. N. (2016). Pengaruh Pengalaman Membeli Produk Fashion Terhadap Niat Membeli Kembali Melalui Kepuasan Dan Kepercayaan Pelanggan. Jurnal Manajemen, Strategi Bisnis Dan Kewirausahaan, 10(1), 85-97.

Rahayu, A., \& Adi, L. (2013). Analisis Nilai Pengalaman Berbelanja Online Melalui Experiential Marketing. Jurnal Ilmu Manajemen \& Bisnis, 04(01), $1-15$. 
Sembiring, Inka Janita., Suharyono., dan Kusumawati, A. (2014). Pengaruh Kualitas Produk Dan Kualitas Pelayanan Terhadap Kepuasan Pelanggan Dalam Membentuk Loyalitas Pelanggan ( Studi pada Pelanggan McDonald ' s MT . Haryono Malang ). Jurnal Administrasi Bisnis, 15(1), 1-10.

Tambunan, Samuel., Handayani, W. (n.d.). Minat Beli Ulang Kartu Perdana Nomor Cantik Simpati (Studi Dicomtech Shop Surabaya ), 85-92.

Thamizhvanan, A., \& Xavier, M. J. (2013). Determinants of customers' online purchase intention: an empirical study in India. Journal of Indian Business Research, 5(1), 17-32.

Wahid, A., Kassim, M., Igau, O. A., Harun, A., \& Tahajuddin, S. (2014). Mediating Effect of CustomerSatisfaction on Perceived Product Quality , Perceived Value, and Their Relation to Brand Loyalty. International Journal of Research in Management \& Business Studies, 1(2). 